\title{
Physical synthesis of iron oxide nanoparticles and their biological activity in vivo
}

Yurii A. Kurapov ${ }^{1} \cdot$ Elena M. Vazhnichaya ${ }^{2} \cdot$ Stanislav E. Litvin $^{1,4}$ (D) Sergey M. Romanenko ${ }^{1} \cdot$ Gennadii G. Didikin $^{1}$. Tatiana A. Devyatkina ${ }^{2} \cdot$ Yevhen V. Mokliak $^{2}$. Elena I. Oranskaya ${ }^{3}$

๑) Springer Nature Switzerland AG 2018

\begin{abstract}
The physical synthesis of iron oxide nanoparticles obtained from the vapor phase using the electron beam physical vapor deposition method is considered. The results of studying the structure of porous condensates of iron-sodium chloride compound, chemical and phase compositions, as well as nanoparticles size are presented. With a rapid removal from vacuum, iron nanoparticles are oxidized in the air to magnetite. In the initial state, they have significant sorption capacity with respect to oxygen and moisture, therefore, with further heating in the air, the porous condensate mass decreases up to the temperature $650^{\circ} \mathrm{C}$, primarily due to the desorption of physically sorbed moisture. Physically adsorbed oxygen participates in oxidation of $\mathrm{Fe}_{3} \mathrm{O}_{4}-\mathrm{Fe}_{2} \mathrm{O}_{3}$ in the range of $380-650^{\circ} \mathrm{C}$. An increase in condensation temperature is accompanied by an increase of nanoparticle size, as a result of which the total surface area of nanoparticles is significantly reduced, and, consequently, their sorption capacity is decreased. Even without stabilization, such nanoparticles studied as ex tempore prepared aqueous dispersion have characteristic anti-anemic effect in the laboratory animals that can be used in medicine.
\end{abstract}

Keywords EB-PVD · Iron oxide nanoparticles · Sorption · Phase composition · Colloid systems · Anti-anemic effect

\begin{tabular}{|c|c|c|c|}
\hline \multicolumn{2}{|c|}{ Abbreviations } & \multirow{2}{*}{$\begin{array}{l}\text { NPs } \\
p\end{array}$} & \multirow{2}{*}{$\begin{array}{l}\text { Nanoparticles } \\
P \text {-value, used in statistical hypothesis testing }\end{array}$} \\
\hline DLS & Dynamic light scattering & & \\
\hline DTA & Differential thermal analysis & $\mathrm{RBC}$ & Red blood cells count \\
\hline EB-PVD & Electron beam physical vapor deposition & RDW & Width of erythrocytes distribution curve \\
\hline EDS & Energy-dispersive X-ray spectroscopy & Rt & Reticulocytes \\
\hline $\mathrm{Fe}_{3} \mathrm{O}_{4}$ & Magnetite, iron(II, III) oxide & SEM & Scanning electron microscope \\
\hline $\mathrm{Fe}_{2} \mathrm{O}_{3}$ & Hematite, iron(III) oxide & SPIONs & Superparamagnetic iron oxide nanoparticles \\
\hline $\mathrm{Y}-\mathrm{Fe}_{2} \mathrm{O}_{3}$ & Maghemite, iron(III) oxide & $\mathrm{T}$ & Temperature \\
\hline $\mathrm{Hb}$ & Hemoglobin & TEM & Transmission electron microscopy \\
\hline Hct & Hematocrit & TGA & Thermogravimetric analyzer \\
\hline $\mathrm{m} / \mathrm{m}_{0}$ & Relative change of mass of TGA & $\mathrm{T}_{\mathrm{m}}$ & Melting temperature \\
\hline $\mathrm{MCH}$ & Mean corpuscular hemoglobin & $\mathrm{T}_{\mathrm{S}}^{\mathrm{m}}$ & Substrate temperature \\
\hline $\mathrm{MCHC}$ & Mean corpuscular hemoglobin concentration & XRD & X-ray diffraction \\
\hline MCV & Mean corpuscular volume & & \\
\hline $\mathrm{NaCl}$ & dium chloride & & \\
\hline
\end{tabular}

$\triangle$ Stanislav E. Litvin, litvin@paton.kiev.ua| ${ }^{1}$ E. O. Paton Electric Welding Institute of the National Academy of Science of Ukraine, 11 Kazymyr Malevych Street, Kyiv 03150, Ukraine. ${ }^{2}$ Higher State Educational Establishment of Ukraine “Ukrainian Medical Stomatological Academy", 23 Shevchenko Street, Poltava 36011, Ukraine. ${ }^{3}$ Chuiko Institute of Surface Chemistry of the National Academy of Science of Ukraine, 17 General Naumov Street, Kyiv 03164, Ukraine. ${ }^{4} 68$ Antonovych St., Kyiv 03150, Ukraine.

SN Applied Sciences (2019) 1:102 | https://doi.org/10.1007/s42452-018-0110-z 


\section{Introduction}

The most studied are nanoparticles (NPs) of iron ( $\mathrm{Fe}$ ) oxides-magnetite $\left(\mathrm{Fe}_{3} \mathrm{O}_{4}\right)$ and maghemite $\left(\gamma-\mathrm{Fe}_{2} \mathrm{O}_{3}\right)$ which are applied in electronics and medicine [1-3]. The greatest number of works is devoted to the investigation of magnetite NPs of up to $20 \mathrm{~nm}$ size which are in superparamagnetic state at room temperature $[4,5]$. They are characterized by practically zero residual magnetization that is especially important for medical and biological applications, for example, at transport of drugs through small-diameter blood vessels when particles aggregation is highly undesirable [6].

Multifunctional $\mathrm{Fe}_{5} \mathrm{C}_{2} \mathrm{NPs}$ exhibit high functional properties in magnetic resonance imaging and photothermal therapy due to their unique core/shell structure with a magnetic core and carbon shell [7]. In [8] synthesized monodisperse $\mathrm{Au}-\mathrm{Fe}_{2} \mathrm{C}$ Janus NPs, which are multifunctional entities for cancer theranostics and showed a significant photothermal effect with $30.2 \%$ calculated photothermal transduction efficiency under $808 \mathrm{~nm}$ laser irradiation in vitro.

In recent years many works have been devoted to studying core-shell superparamagnetic iron oxide nanoparticle (SPIONs) clusters of about $80 \mathrm{~nm}$ size $[9,10]$. The authors have investigated the magnetic properties of such a cluster of $10 \mathrm{~nm}$ maghemite NPs in amorphous $15 \mathrm{~nm}$ thick silicon dioxide shell. It turned out that along with superparamagnetic properties the cluster registers high magnetic moment which is especially important for control by an external magnetic field. Magnetic $\mathrm{N}$-enriched $\mathrm{Fe}_{3} \mathrm{C} /$ graphitic carbon instead of $\mathrm{Pt}$ is also very interesting as an electrocatalyst for the oxygen reduction reaction. It has higher selective operational properties, than commercial Pt/C catalysts in $0.10 \% \mathrm{KOH}$ solution. The materials exhibit excellent magnetic properties and oxygen reduction reaction activities [11].

Many works are devoted to development of new methods for obtaining and stabilizing metal NPs. Chemical methods of particle synthesis are the leading techniques. Among them liquid-phase chemical condensation method proposed by Elmore is the most common [12]. In this method, the nucleation and growth of particles occurs in the volume or on the surfaces of different nature, shape and sizes that come into contact with the liquid phase [13-15]. Sol-gel combustion synthesis to produce SPIONs is also notable $[16,17]$. It allowed producing NPs with high magnetization and magnetic moment.

The first mention of producing magnetic NPs by physical method (molecular beam method) was made in references $[18,19]$. It is based on physical processes of evaporation or sputtering of substances with subsequent deposition of the vapor phase in vacuum, atmosphere of inert or active gases. In this case, radiation, electron beam, laser, and ion-plasma heat sources are used for evaporation and sputtering respectively. Methods for obtaining magnetic NPs and their practical applications are described in the relevant reviews, for example [20, 21].

The method of electron beam evaporation of various substances in vacuum with subsequent condensation of vapor flows, which has been applied at deposition of functional and structural coatings with micro- and nanoscale structure, is also used for synthesis of metal NPs [22-26]. This method, in addition to high productivity, is also notable for its versatility at selection of various inorganic and organic matrices for the conservation of metal NPs and their oxides. The choice of sodium chloride $(\mathrm{NaCl})$ as a matrix was justified by the fact that this material, when condensed in the temperature range $T<0.3 T_{m}$ ( $T_{m}$ is melting temperature), is characterized by open porous structure [27]. Condensing in vacuum in the open pores of this matrix, iron NPs freely oxidize to magnetite in the air. Moreover, $\mathrm{NaCl}$ is widely used in medicine as an ingredient of many drugs due to its biological compatibility with living tissues and good solubility in water.

As was noted, biology and medicine are one of the main directions of practical application of magnetite NPs $[28,29]$. This is due to magnetic properties and the presence of iron in their composition. Therefore, such NPs have anti-anemic effect due to the replenishment of total iron pool in the body, ability to influence the relaxation time of surrounding protons that improves visualization of certain structures in magnetic resonance imaging, hyperthermic action, as well as the transport effect, consisting in medicinal drugs delivery to target cells by active targeting [30-33].

Medical use of magnetite NPs requires their stabilization in liquid medium that causes some problems because of the fact that stabilizing substances are capable of modifying the pharmacokinetics of iron oxide NPs and their interaction with the cells [34-36]. According to this point of view, magnetite NPs, which were deposited in porous, easily soluble and biocompatible matrix, are of considerable practical interest.

The aim of presented research was to synthesize superparamagnetic iron oxide NPs by simultaneous evaporation of iron and sodium chloride and to investigate the effects of iron concentration and condensation temperature on the sorption properties, size and phase composition of these NPs, as well as to study the biological activity of such particles at anemia caused by acute blood loss. 


\section{Methods}

Synthesis of NPs was carried out by condensation of mixed molecular flows of iron and salt in vacuum electron beam installation [37]. An iron ingot was placed into a water-cooled crucible of $50 \mathrm{~mm}$ diameter, and pressed cylinder of $\mathrm{NaCl}$ was placed in the adjacent crucible. Vacuum of $(1.3-2.6) \times 10^{-2} \mathrm{~Pa}$ was created in the chamber. Surfaces of the ingot and crucible were heated by electron beam guns up to melting. As a result, a mixed vapour flow of iron and $\mathrm{NaCl}$ was formed. It was condensed on a water-cooled substrate, where the temperature was maintained at $40-50^{\circ} \mathrm{C}$. After air intake and complete depressurization of the chamber, the condensate was stripped from the substrate and NPs were examined both in dry powder and in the colloidal solution.

The microstructure and content of elements in the condensate were investigated by scanning electron microscopes VEGA 3 (Tescan, Czech Republic) and CamScan (Cambridge CamScan SEM) with the INCA200 Energy X-ray imager (Oxford Inca Energy 200 EDS system). Investigation of the particles morphology and phase composition was carried out by transmission electron microscopy (TEM) method using HITACHI H-800 microscope (Hitachi, Japan) at the accelerating voltage of $100 \mathrm{kV}$. X-ray diffraction (XRD) was studied by DRONUM1 diffractometer with cobalt $\left(\mathrm{CoK}_{a}\right)$ radiation and graphite monochromator in reflected beam with the angle range of $10-85$ degrees. The average crystallite size was estimated by the Scherrer equation. Semi-quantitative phase analysis was performed using Match! program. The processes of iron oxidation in the salt matrix in air were studied by increasing the temperature to $650^{\circ} \mathrm{C}$ at a rate of $10^{\circ} \mathrm{C} / \mathrm{min}$ using a thermogravimetric analyzer TGA-7 (Perkin Elmer, USA). The size of NPs in the colloidal system was determined by the method of dynamic light scattering (DLS) $[38,39]$ in Zeta Sizer-3000 laser correlation spectrometer (Malvern, UK).

Condensate with magnetite NPs was dissolved in deionized water at a ratio of $1 \mathrm{mg} / 1 \mathrm{ml}$ and was studied for stability and hydrodynamic particle size using the DLS method, as described above.

Obtained magnetite NPs were used in the experiments on laboratory animals aimed to determine their biological activity. These experiments were performed on 28 abino male Wistar rats (Rattus norvegicus) with body weight $183-221 \mathrm{~g}$. The rats were randomized, labeled, divided into groups and kept in the standard conditions. The experiments were approved by Commission on Bioethics of Higher State Educational Establishment of Ukraine "Ukrainian Medical Stomatological
Academy". Acute blood loss was simulated by puncture of the heart and removal of $25 \%$ of circulating blood volume under the ether anesthesia (3-4 $\mathrm{ml} / \mathrm{kg}$ of body weight) at the surgical stage [40].

Magnetite NPs deposited in $\mathrm{NaCl}$ matrix were used for pharmacological correction of this experimental pathology. They were dispersed ex tempore in the water for injections and administered to the rats intraperitoneally in a dose of $25 \mathrm{mg} / \mathrm{kg}$ body weight $(6.75 \mathrm{mg} \mathrm{Fe} / \mathrm{kg}$ ) immediately after the blood loss. Blood samples were obtained from the heart of animals under the ether anesthesia 3 and $72 \mathrm{~h}(\mathrm{~h})$ after the blood loss. Hematological parameters were studied: red blood cells count (RBC), hematocrit (Hct), hemoglobin, $(\mathrm{Hb})$, mean corpuscular volume (MCV), mean corpuscular hemoglobin concentration $(\mathrm{MCHC})$, mean corpuscular hemoglobin $(\mathrm{MCH})$, as well as the width of erythrocytes distribution curve (RDW). These indices were examined using hematology analyzer MicroCC-20Plus Vet (High Technology Inc., USA) programmed for blood parameters of albino rats [41]. Reticulocytes (Rt) content was determined using supravital staining with methylene blue during which ribonucleic acid-containing structures appear as granular mesh substance [42]. Painted smears were examined by microscope AmScope T490B-10MT (United Scope LLC, USA) with $\times 100$ lens. Digital findings were statistically processed by standard software package Statistica for Windows 8.0. The mean $M$, and its standard error $m$ were calculated, and the significance of differences between groups was evaluated using one-way ANOVA analysis with post hoc test Fisher LSD.

\section{Results and discussion}

The appearance (Fig. 1a) and the surface of obtained $\mathrm{Fe}-\mathrm{NaCl}$ condensates (Fig. 1b) corresponded to the first zone of low-temperature formation of the nanocrystalline structure [43]. Studies of the macrostructure and content of elements on transverse cleavage of porous $\mathrm{Fe}-\mathrm{NaCl}$ condensate showed the presence of large amount of oxygen (O) adsorbed by NPs from the air after depressurization of vacuum chamber (Fig. 2, Table 1).

$\mathrm{X}$-ray phase analysis (Fig. 3a) showed that iron particles in the salt matrix are conserved in two forms: $a-F e$ and $\mathrm{Fe}_{3} \mathrm{O}_{4}$. When the particles are removed from the matrix by salt dissolving in the water, oxidation of pure iron to $\mathrm{Fe}_{3} \mathrm{O}_{4}$ and $\mathrm{FeOOH}$ oxide-hydroxide takes place (Fig. 3b, Table 2). Before dissolving in water and preparing colloidal solutions, the condensate was ground into a powder to the micron size. Figure 4 shows the granulometric analysis of the resulting powder after many hours of condensate grinding in the agate mortar. 

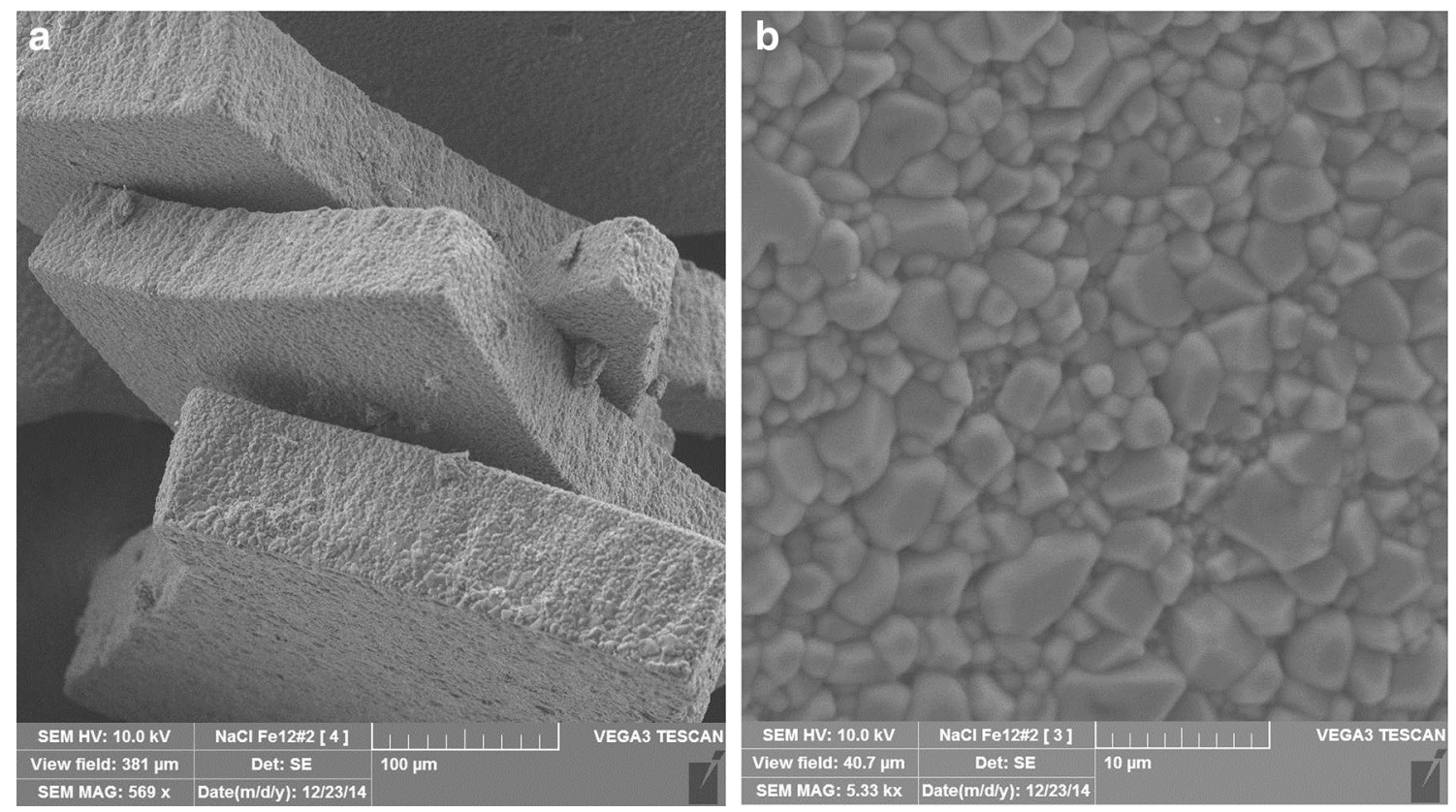

Fig. 1 3D image (a) and surface view (b) of the initial condensate 29 wt $\% \mathrm{Fe}+\mathrm{NaCl}$ obtained by the EB-PVD method at substrate temperature of $40^{\circ} \mathrm{C}$

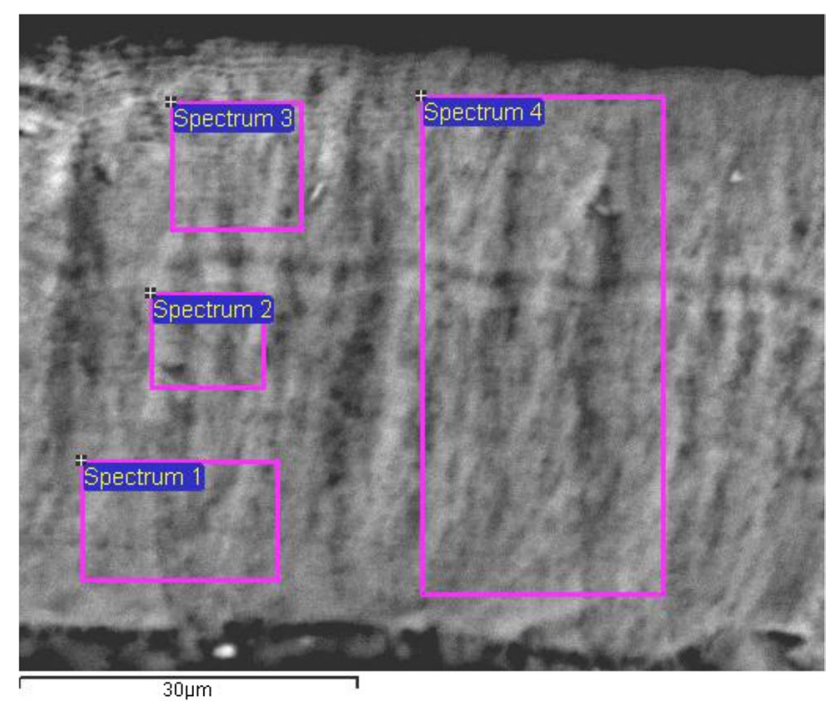

Fig. 2 Microstructure of the transverse cleavage of the initial condensate $(29 \mathrm{wt} \% \mathrm{Fe}+\mathrm{NaCl})$ obtained by the EB-PVD method at substrate temperature of $40^{\circ} \mathrm{C}$ (see Table 1)

TEM of thin cleavages of the condensate revealed the presence of nanoscale substance with advantageous phase composition corresponding to magnetite $\left(\mathrm{Fe}_{3} \mathrm{O}_{4}\right)$. Consequently, when the condensate is extracted from the vacuum into the air, oxygen and moisture of the air freely penetrate and actively interact with developed open surface of iron NPs interspersed in the micro- and nanoscale pores of salt matrix porous structure [27]. When
Table 1 Elemental composition of transverse cleavage of porous condensate $29 \mathrm{wt} \% \mathrm{Fe}+\mathrm{NaCl}$, obtained at substrate temperature of $40{ }^{\circ} \mathrm{C}$ (see Fig. 2)

\begin{tabular}{|c|c|c|c|c|}
\hline \multirow[t]{2}{*}{ Spectrum } & \multicolumn{4}{|l|}{ wt $\%$} \\
\hline & $\mathrm{Fe}$ & 0 & $\mathrm{Na}$ & $\mathrm{Cl}$ \\
\hline Spectrum 1 & 28.6 & 23.3 & 19.8 & 28.3 \\
\hline Spectrum 2 & 29.1 & 20.1 & 19.7 & 31.1 \\
\hline Spectrum 3 & 34.8 & 22.4 & 17.2 & 25.6 \\
\hline Spectrum 4 & 29.0 & 25.0 & 19.4 & 26.6 \\
\hline
\end{tabular}

the condensate is quickly removed from vacuum, iron oxide is formed with the release of heat that is confirmed by heating of the condensate separated from the substrate and placed on paper.

Moreover, iron oxide NPs can additionally adsorb physically bound oxygen and moisture to their surface [22]. Taking into account that high adsorption capacity for oxygen is inherent in greater degree to NPs of small size, it can properly affect the study of oxygen content in the condensate with different amounts of iron. Indeed, the ratio of oxygen atomic percentage to the iron atomic percentage depends on the amount of iron, decreases with increase of its content in the condensate and exceeds this value for stoichiometric composition of $\mathrm{Fe}_{3} \mathrm{O}_{4}$, equal to 1.33 (Fig. 5, $40{ }^{\circ} \mathrm{C}$ curve); and this ratio approaches the stoichiometric one only at about 30 at. \% content of iron in the condensate, when the probability of collision of NPs in the mixed 


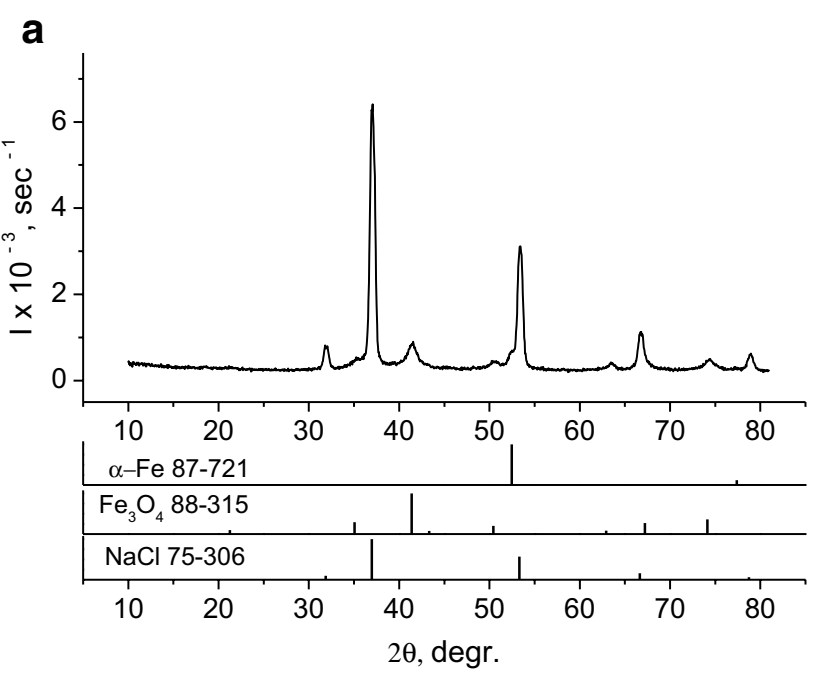

b

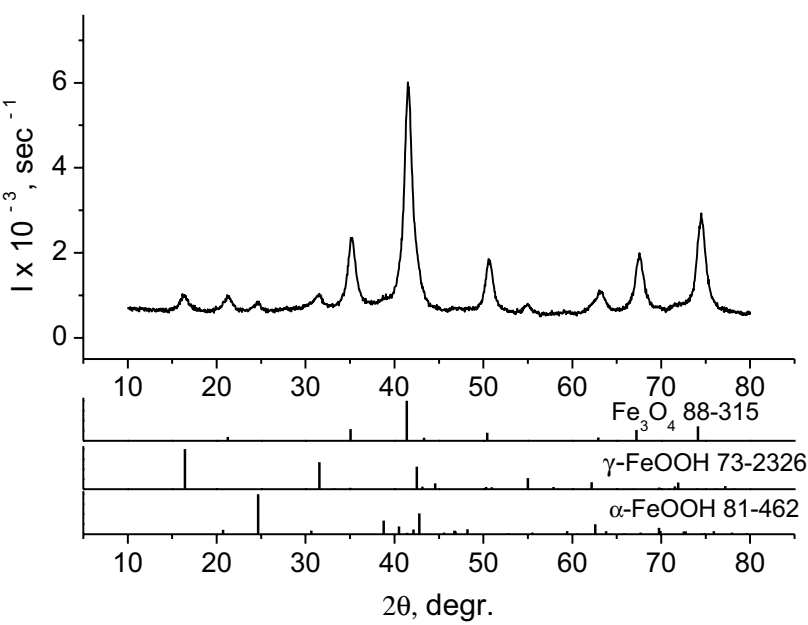

Fig. 3 Diffraction patterns of condensate samples (29 wt $\%$ $\mathrm{Fe}+\mathrm{NaCl}$ ) initially (a) and after $\mathrm{NaCl}$ washing out (b)

vapor flow and during condensation on the substrate is high, leading to some increase in NPs size (Fig. 5, curve $40^{\circ} \mathrm{C}$ ).

This is another indication of the high adsorption capacity of small NPs [13]. One of the main reasons for the change in physical and chemical properties of small particles at reduction of their size, is an increase in the relative fraction of surface atoms which are under other conditions (coordination number, symmetry of local environment, etc.) than the atoms inside the bulk phase. Particle size reduction leads to the increase in the role of surface energy.

However, the condensation temperature has a greater influence on NPs size (Fig. 6). TEM study of particles suspension obtained by condensate dissolving in the aqueous medium revealed the presence of a nanosized substance (Fig. 7a, c, e). The average particle size increases from 3-4 $\mathrm{nm}$ up to $15-20 \mathrm{~nm}$ as the substrate temperature rises from 20 to $200^{\circ} \mathrm{C}$ (Fig. 6). As the particle size grows, the diffraction rings become clear (Fig. 7b, d, e). The phase composition of the particles corresponds to $\mathrm{Fe}_{3} \mathrm{O}_{4}$.

As the temperature of substrate rises, the size of NPs increases, resulting in significant reduction of NPs total surface area that leads to decrease in the ratio of oxygen atomic percentage to the atomic percentage of iron depending on the amount of iron (Fig. 5, $400^{\circ} \mathrm{C}$ curve).

The kinetics of relative change in the mass of $\mathrm{Fe}-\mathrm{NaCl}$ porous condensate heated to $650^{\circ} \mathrm{C}$ and cooled in the air, studied by thermogravimetric analysis (TGA), allows us considering these sorption processes in greater detail. As the temperature rises, the mass of $\mathrm{Fe}-\mathrm{NaCl}$ porous condensate decreases up to the temperature of $650^{\circ} \mathrm{C}$ (Fig. 8, curve 2), whereas the kinetics of relative change in the mass of porous $\mathrm{NaCl}$ (no Fe) condensate heated to $650^{\circ} \mathrm{C}$ and cooled in the air shows (Fig. 8, curve 1) practically no mass change connected with moisture adsorption.

The decrease in mass may be due to the competitive nature of adsorption from the air of different gases having different adsorption times [44-46] and/or large range of binding energies of water molecules to oxides surface $[47,48]$. For example, water molecules have adsorption time of at least an order of magnitude greater than that of the main components of the air-oxygen and nitrogen. This means that penetration of water molecules into the condensate to nanoscale particles lags behind in time by an order of magnitude relative to the main components
Table 2 Phase composition of the initial condensate $29 \mathrm{wt} \%$ $\mathrm{Fe}+\mathrm{NaCl}$ and after washing with $\mathrm{NaCl}$

\begin{tabular}{lllc}
\hline Sample & Phase composition & $\begin{array}{l}\text { Mean crystallites size } \\
(\mathrm{nm})\end{array}$ & $\begin{array}{l}\text { Phase } \\
\text { content } \\
\text { (wt\%) }\end{array}$ \\
\hline Condensate & $\mathrm{NaCl} \mathrm{JCPDS} \mathrm{\#} \mathrm{75-306}$ & 20 & 89 \\
& $\mathrm{a}-\mathrm{Fe}$ JCPDS \#87-721 & 20 & 2 \\
& $\mathrm{Fe}_{3} \mathrm{O}_{4}$ JCPDS \# 88-315 & 11 & 9 \\
Condensate washed out & $\mathrm{Fe}_{3} \mathrm{O}_{4}$ JCPDS \# 88-315 & 10 & 84 \\
from $\mathrm{NaCl}$ & $\mathrm{Y}-\mathrm{FeOOH}$ JCPDS \# 73-2326 & 8 & 9 \\
& $\mathrm{a}-\mathrm{FeOOH}$ JCPDS \# 81-462 & 8 & 7 \\
\hline
\end{tabular}




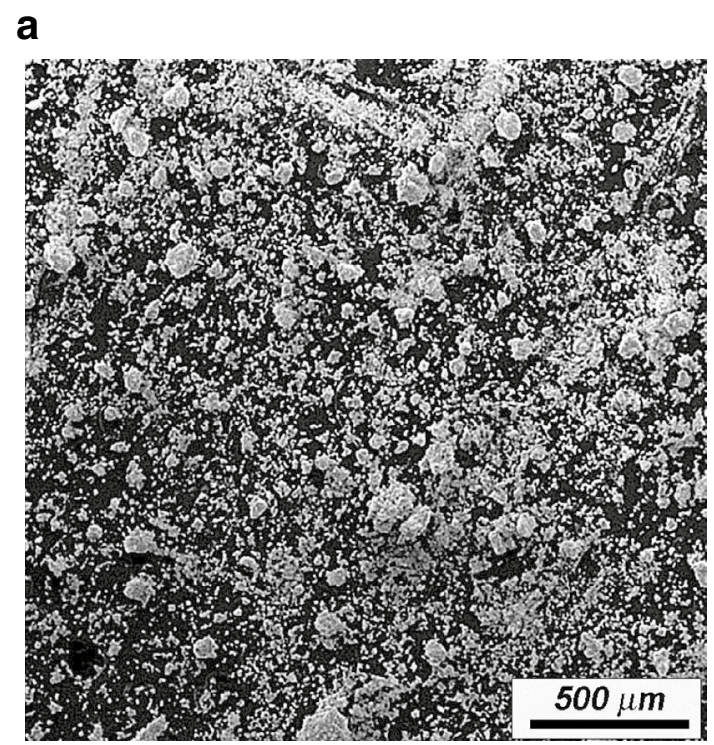

b

\begin{tabular}{|lcc|}
\hline granules count * & 7107 & units \\
mean size $\dagger$ & 15.1 & $\mu \mathrm{m}$ \\
standard deviation & 8.9 & $\mu \mathrm{m}$ \\
variation (dispersion) & 59.0 & $\%$ \\
minimum & 2.8 & $\mu \mathrm{m}$ \\
maximum & 94.9 & $\mu \mathrm{m}$ \\
dispersion & 92.1 & $\mu \mathrm{m}$ \\
asymmetry & 54.9549 & \\
width & 94.6455 & \\
\hline
\end{tabular}

* measurement area $4 \mathrm{~mm}^{2}$

$\dagger 95 \%$ confidence interval for mean granule size $15.12 \pm 0.21 \mu \mathrm{m}$

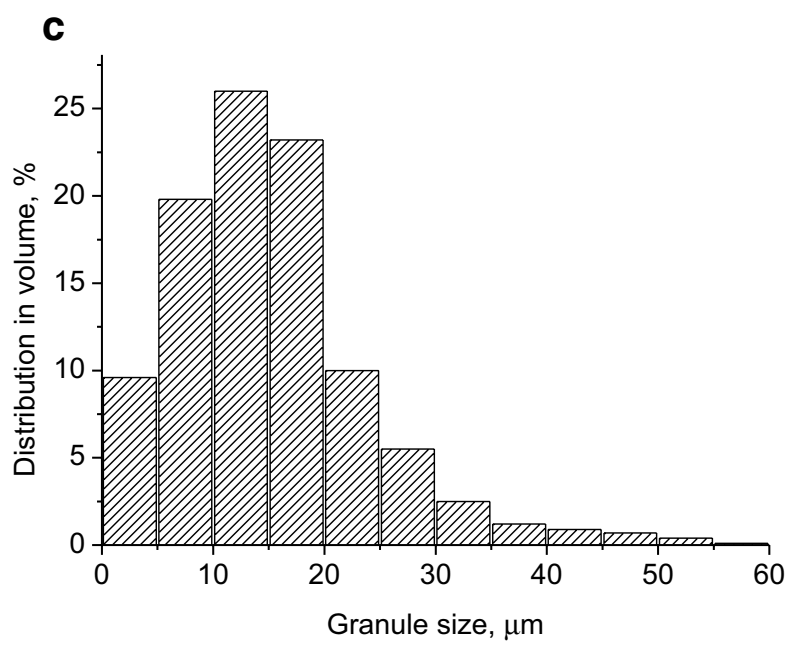

Fig. 4 The microstructure (a), granules size distribution (b) and volumetric distribution (c) of the particle size in the powder after the grinding of condensate ( $29 \mathrm{wt} \% \mathrm{Fe}+\mathrm{NaCl}$ ) processed by Statgraphics program

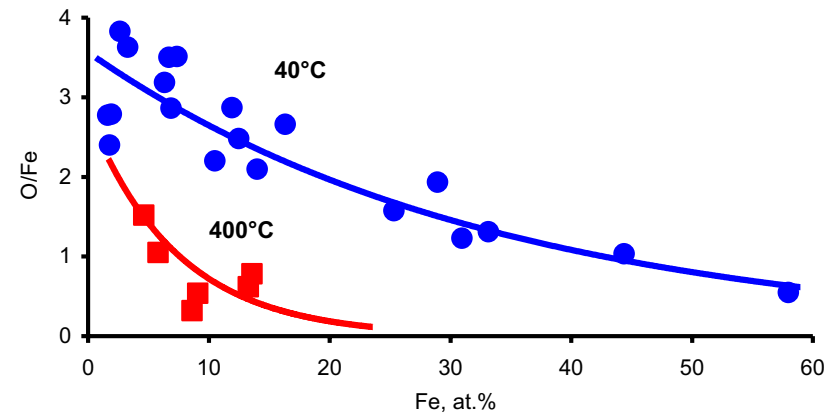

Fig. 5 The ratio of $\mathrm{O} / \mathrm{Fe}$ in $\mathrm{Fe}-\mathrm{NaCl}$ condensates obtained at $40{ }^{\circ} \mathrm{C}$ and $400{ }^{\circ} \mathrm{C}$ depending on the Fe content

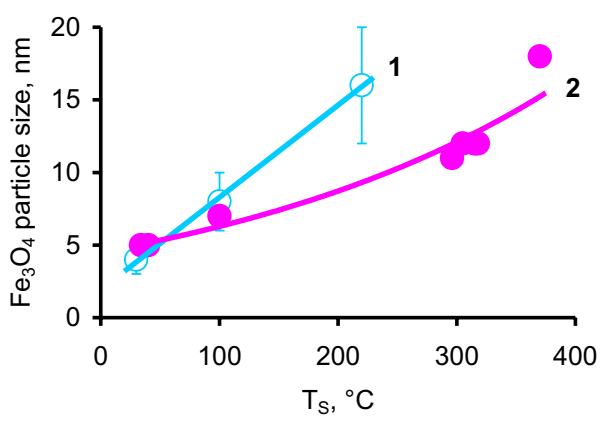

Fig. 6 Change in the average particle size of $\mathrm{Fe}_{3} \mathrm{O}_{4}$ in $\mathrm{Fe}-\mathrm{NaCl}$ condensates as a function of substrate temperature $\mathrm{T}_{\mathrm{S}}$. 1-TEM study, 2-XRD 
a

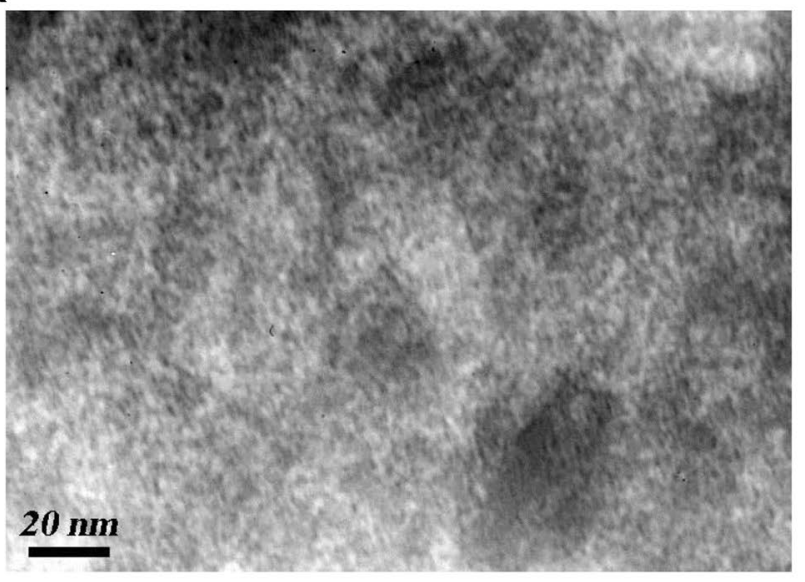

C

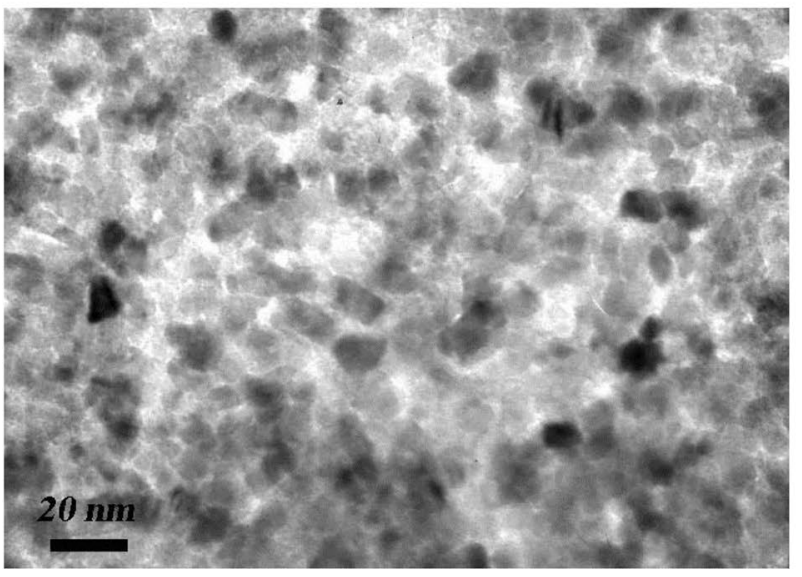

e

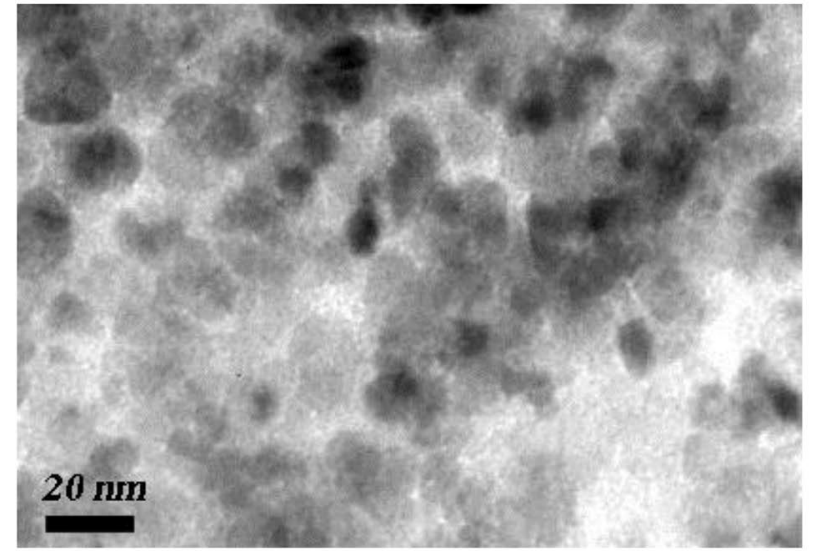

b

$\mathrm{Fe}_{3} \mathrm{O}_{4}$

(440)

(511)

(422)

(400)

(311)

(220)

(111)

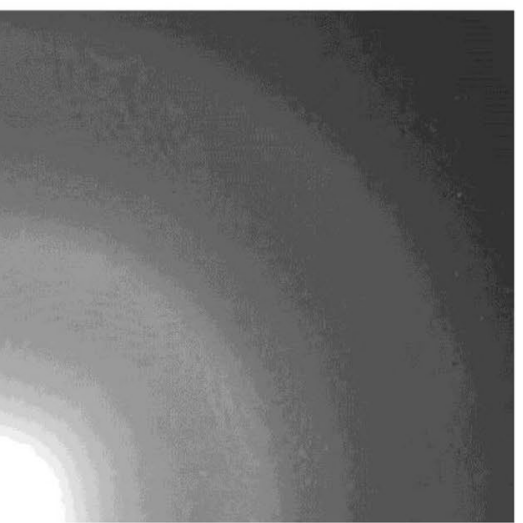

d

$\mathrm{Fe}_{3} \mathrm{O}_{4}$

(440)

(511)

(422)

(400)

(311)

(220)

(111)

f

$\mathrm{Fe}_{3} \mathrm{O}_{4}$

(440)

(511)

(422)

(400)

(311)

(220)

(111)

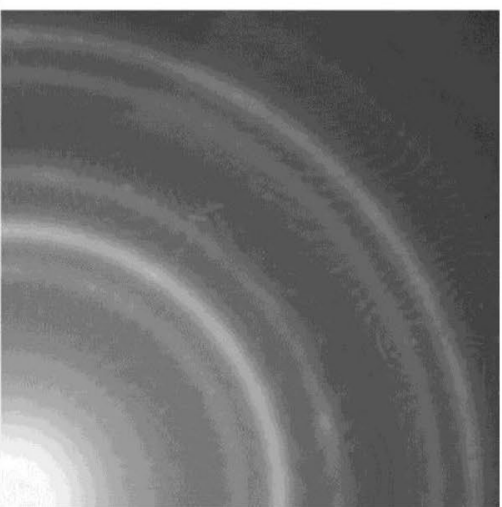

Fig. 7 Microstructure $(\mathbf{a}, \mathbf{c}, \mathbf{e})$ and X-ray diffraction patterns $(\mathbf{b}, \mathbf{d}, \mathbf{f})$ of $\mathrm{Fe}_{3} \mathrm{O}_{4}$ nanoparticles in aqueous colloids of $\mathrm{Fe}-\mathrm{NaCl}$ condensates as a function of substrate temperature $\mathrm{T}_{\mathrm{s}}: \mathbf{a}, \mathbf{b}-40^{\circ} \mathrm{C} ; \mathbf{c}, \mathbf{d}-100^{\circ} \mathrm{C} ; \mathbf{e}, \mathbf{f}-220^{\circ} \mathrm{C}$

of the air [44]. Thus, at the first moment of condensate contact with air, oxygen of the air is consumed to form iron oxide with high heat release. In their turn, the iron oxide NPs can additionally adsorb oxygen, nitrogen and moisture onto their surfaces. During the lagging of water molecules, the vacancies on the adsorbent surface are occupied by nitrogen and oxygen molecules, but after the arrival of additional water molecules they are also 


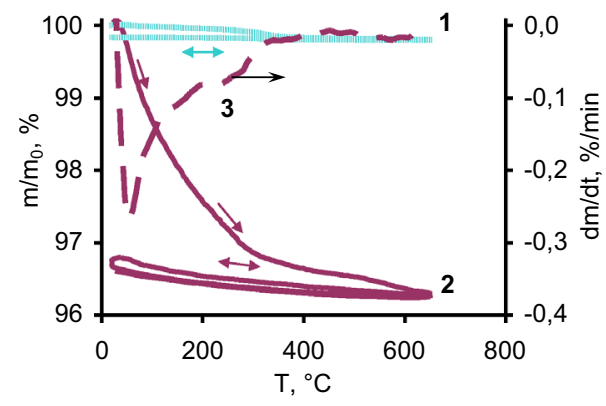

Fig. 8 Kinetics of the relative change in the mass of condensates $\mathrm{NaCl}$ (1) and $29 w t \% \mathrm{Fe}+\mathrm{NaCl}$ (2) with the differential curve (3) for cyclic heating/cooling in the air

displaced due to the longer adsorption time of the water. Since the molecular weight of water is almost half that of nitrogen and oxygen, and the areas occupied by molecules are comparable, it is logical to expect a decrease in the total mass of adsorbates [44].

Consequently, at the first stage (Fig. 8), when the porous condensate is heated to the temperature of $200^{\circ} \mathrm{C}$, desorption of physically sorbed water occurs. On the Differential Thermal Analysis (DTA) curve, this process corresponds to the observed endoeffect with a peak at $100-120^{\circ} \mathrm{C}$ (Fig. 8, curve 3 ). Then, in the range of $200-650^{\circ} \mathrm{C}$, there is a further change of mass due to removal of chemically bound water (crystallization moisture) and other adsorbates from the structure of $\mathrm{Fe}-\mathrm{NaCl}$ condensate. Simultaneously, in the range of $380-650^{\circ} \mathrm{C}$, oxidation [22] of $\mathrm{Fe}_{3} \mathrm{O}_{4}$ to $\mathrm{Fe}_{2} \mathrm{O}_{3}$ takes place due to the remaining fraction of oxygen physically adsorbed by $\mathrm{Fe}_{3} \mathrm{O}_{4} \mathrm{NPs}$.

The resulting condensate of $\mathrm{Fe}_{3} \mathrm{O}_{4} \mathrm{NPs}$ was dissolved in water. The sample contained $1 \mathrm{mg}$ of NPs condensate in $1 \mathrm{ml}$ of bidistilled water, was transparent and of a brownish color. Within 3-5 min after shaking, it formed a dark brown sediment. When studying the particle size distribution in the polymodal approximation, two fractions were determined in the sample. The first one was formed by particles of 13-120 nm size with a maximum at $23 \mathrm{~nm}$. Their amount was $99.9 \%$, and the mass fraction was equal to $46 \%$ of all detected NPs. The second fraction contained particles ranging in size from 209 to $3300 \mathrm{~nm}$ with a maximum at $209 \mathrm{~nm}$ [27]. The number of such particles was $0.1 \%$, and their mass fraction was $54 \%$. So, aqueous dispersion of magnetite NPs after preparation contained nanosized particles in a predominating amount and could be administered to the laboratory animals as nanofluid.

Condensate of magnetite NPs obtained by electron beam physical vapor deposition (EB-PVD) was tested for its biological activity. When studying the biological activity of above described NPs, acute blood loss without the administration of nanofluid served as control pathology. In this control group $3 \mathrm{~h}$ after the removal of blood, RBC decreased by $18 \%(p<0.001), \mathrm{Hb}$ diminished by $40 \%$ $(p<0.001)$, and Hct decreased by $24 \%(p<0.001)$, as compared to intact animals (Table 3 ). These changes were accompanied by significant decrease in the mean volume of red blood cells (MCV index) $(p<0.05)$ without any changes of RDW. The $\mathrm{MCH}$ and $\mathrm{MCHC}$ indices which characterize the saturation of erythrocytes with hemoglobin decreased by $27 \%$ and $21 \%$, respectively $(p<0.001)$, as compared to those of intact rats. Such hematological changes are typical to early period of acute blood loss and testify the development of hypochromic anemic condition. In this period, magnetite NPs use increased RBC by $9 \%(p<0.05)$ as compared to control pathology (see Table 3 ). The level of $\mathrm{Hb}$ also increased by $25 \%$ $(p<0.005)$, and Hct-by $13 \%(p<0.05)$ in comparison to those without NPs administration. These changes

Table 3 Effect of magnetite nanoparticles $(6.75 \mathrm{mg} \mathrm{Fe} / \mathrm{kg}$ ) deposited in $\mathrm{NaCl}$ crystals on hematological parameters in acute blood loss $(\mathrm{M} \pm \mathrm{m})$

\begin{tabular}{lcllll}
\hline Parameters & \multicolumn{2}{l}{ Groups of animals } & & \\
\cline { 2 - 6 } & Intact $(\mathrm{n}=8)$ & $\begin{array}{l}\text { Acute blood } \\
\text { loss + solvent } \\
3 \mathrm{~h}(\mathrm{n}=5)\end{array}$ & $\begin{array}{l}\text { Acute blood loss + magnet- } \\
\text { ite nanoparticles } \\
3 \mathrm{~h}(\mathrm{n}=5)\end{array}$ & $\begin{array}{l}\text { Acute blood } \\
\text { loss + solvent } \\
72 \mathrm{~h}(\mathrm{n}=5)\end{array}$ & $\begin{array}{l}\text { Acute blood } \\
\text { loss + magnetite nano- } \\
\text { particles } \\
72 \mathrm{~h}(\mathrm{n}=5)\end{array}$ \\
\hline $\mathrm{RBC}\left(\times 10^{12} / \mathrm{L}\right)$ & $7.79 \pm 0.20$ & $6.39 \pm 0.13^{*}$ & $6.98 \pm 0.12^{*} \dagger$ & $5.71 \pm 0.12^{*}$ & $6.42 \pm 0.16^{*} \dagger$ \\
$\mathrm{Hb}(\mathrm{g} / \mathrm{L})$ & $136.6 \pm 3.7$ & $81.6 \pm 4.1^{*}$ & $102.4 \pm 3.1^{*} \dagger$ & $91.0 \pm 1.3^{*}$ & $105.0 \pm 3.0^{*}+$ \\
$\mathrm{Hct}(\mathrm{units})$ & $0.42 \pm 0.02$ & $0.32 \pm 0.01^{*}$ & $0.36 \pm 0.01^{*} \dagger$ & $0.32 \pm 0.01^{*}$ & $0.37 \pm 0.01^{*}+$ \\
$\mathrm{MCV}\left(\mu \mathrm{m}^{3}\right)$ & $54.3 \pm 1.2$ & $50.0 \pm 1.0^{*}$ & $52.8 \pm 1.6$ & $56.9 \pm 0.3$ & $57.3 \pm 1.4$ \\
$\mathrm{MCH}(\mathrm{pg})$ & $17.55 \pm 0.51$ & $12.88 \pm 0.46^{*}$ & $14.80 \pm 0.46^{*} \dagger$ & $15.84 \pm 0.23^{*}$ & $16.30 \pm 0.30$ \\
$\mathrm{MCHC}(\mathrm{g} / \mathrm{dL})$ & $324.1 \pm 8.8$ & $255.4 \pm 4.41^{*}$ & $281.4 \pm 7.1^{*}$ & $281.6 \pm 3.5^{*}$ & $285.8 \pm 2.2^{*}$ \\
$\mathrm{RDW}(\%)$ & $11.08 \pm 0.35$ & $11.06 \pm 0.52$ & $10.56 \pm 0.32$ & $10.46 \pm 0.13$ & $10.88 \pm 0.69$ \\
$\mathrm{Rt}(\%)$ & $62.3 \pm 5.9$ & $42.2 \pm 3.9^{*}$ & $82.2 \pm 6.2^{*} \dagger$ & $107.0 \pm 2.0^{*}$ & $139.8 \pm 7.4^{*}+$
\end{tabular}

${ }^{*} p<0.05$ as compared to Intact animals; ${ }^{\dagger} p<0.05$ as compared to blood loss with solvent (control); $n$ number of animals in the group 
occurred against the background of the growth of erythrocyte index $\mathrm{MCH}(p<0.05)$ and the tendency to MCHC increase $(p<0.1)$ in the absence of significant changes in MCV and RDW.

$72 \mathrm{~h}$ after the blood removal without correction, significant hematological changes persisted, namely: a decrease in $\mathrm{RBC}(p<0.001)$, lowering in $\mathrm{Hb}(p<0.001)$, and diminishing of Hct $(p<0.001)$ as compared to intact animals, that was similar to the previous observation period (see Table 3). There was a decrease in $\mathrm{MCH}(p<0.02)$ and MCHC $(p<0.005)$ with no changes in other erythrocyte indices.

Corrective influence of NPs in this observation period was manifested by the increase in RBC by $12 \%(p<0.02)$, $\mathrm{Hb}-$ by $15 \%(p<0.02)$ and Hct-by $16 \%(p<0.05)$ as compared to similar parameters at acute blood loss without magnetite NPs administration (see Table 3), even though all the mentioned parameters stayed lower than in the intact animals. In this case, erythrocyte indices were the same as for control pathology.

Bone marrow regenerative reaction was evaluated by the count of Rt in the blood (see Table 3 ). Intact rats had Rt content $62.3 \pm 5.9 \%$ o. $3 \mathrm{~h}$ after the blood loss, this parameter was significantly lower than that in the intact animals $(p<0.02)$. Such development of processes can be explained by both the loss of these cells with the removed blood and accelerated transformation of circulating $\mathrm{Rt}$ to mature red blood cells under the conditions of intense erythropoiesis provoked by blood loss. $72 \mathrm{~h}$ after the removal of blood, Rt content was increased by 1.7 times $(p<0.001)$ as compared to that in the intact animals, which is a natural reaction to compensate blood loss.

After the administration of magnetite NPs and investigation at $3 \mathrm{~h}$ from the removal of blood, Rt content increased and was 1.9 times $(p<0.001)$ greater than that in the control pathology group (see Table 3). After $72 \mathrm{~h}$, the content of $\mathrm{Rt}$ in the animals which received magnetite NPs, also exceeded the control level significantly $(p<0.002)$.

The presence of protective effect within $3 \mathrm{~h}$ after the administration of aqueous dispersion of magnetite NPs may show that these non-stabilized NPs are rapidly distributed in the body, captured by the cells of reticuloendothelial system and included into erythropoiesis. This does not contradict the known data on the pharmacokinetics of magnetite NPs of other origin [34,49].

It should be noted that anti-anemic effect of the single dose of investigated magnetite NPs persists even in the last observation period when hematological parameters are higher than the analogous ones for the blood loss without pharmacological correction. In this case, more intensive increase in the content of Rt evidently supports the fact that used magnetite NPs provide the restoration of key parameters of "red" blood precisely due to the activation of erythron regenerative reaction.
This means that even without stabilization magnetite NPs deposited in the porous matrix of $\mathrm{NaCl}$ and used as ex tempore aqueous dispersion have a characteristic antianemic effect associated with biomedical application.

\section{Conclusion}

Physical synthesis of iron NPs from the vapor phase is possible using the EB-PVD method. With rapid recovery from vacuum, iron NPs are oxidized in the air to magnetite. In the initial state, they have considerable sorption capacity with respect to oxygen and moisture. When heated in the air to $650^{\circ} \mathrm{C}$, the mass of porous condensate decreases due to desorption of physically sorbed moisture. Physically adsorbed oxygen participates in the oxidation of $\mathrm{Fe}_{3} \mathrm{O}_{4}$ to $\mathrm{Fe}_{2} \mathrm{O}_{3}\left(380-650^{\circ} \mathrm{C}\right)$. An increase in the condensation temperature is accompanied by the increase in NPs size resulting in the reduction of total surface area of the nanoparticles and their sorption capacity.

Magnetite NPs deposited in $\mathrm{NaCl}$ crystals by EB-PVD technology can be dispersed in the water and used to correct anemia caused by acute blood loss. In a dose of $6.75 \mathrm{mg} \mathrm{Fe} / \mathrm{kg}$, they produce protective effect on RBC, $\mathrm{Hct}$ and $\mathrm{Hb}$ and activate the regenerative response of the bone marrow of laboratory animals that is manifested by an increase in Rt content in the blood.

\section{Compliance with ethical standards}

Conflict of interest The authors declare that they have no conflict of interest.

\section{References}

1. Revia RA, Zhang M (2016) Magnetite nanoparticles for cancer diagnosis, treatment, and treatment monitoring: recent advances. MaterialsToday 19(3):157-168. https://doi. org/10.1016/j.mattod.2015.08.022

2. Cabuil V (2008) Magnetic nanoparticles: In: Schwarz JA, Contescu Cl, Putyera K (eds) Dekker encyclopedia of nanoscience and nanotechnology, vol 3. CRC Press, Taylor and Francis Group, Boca Raton, Fl, pp 1985-2000. https://www.amazon.com/Dekke r-Encyclopedia-Nanoscience-Nanotechnology-3/dp/08247 50497

3. Willard MA, Kurihara LK, Carpenter EE, Calvin S, Harris VG (2004) Chemically prepared magnetic nanoparticles. Int Mater Rev 49:125-170. https://doi.org/10.1179/095066004225021882

4. Nikolaev VI, Shipilin AM, Zakharova IN (2001) On estimating nanoparticle size with the help of the Mössbauer effect. Phys Solid State 43:1515-1517. https://doi.org/10.1134/1.1395093

5. Thach CV, Hai NH, Chau N (2008) Size controlled magnetite nanoparticles and their drug loading ability. J Kor Phys Soc 52:1332-1335. https://doi.org/10.3938/jkps.52.1332 
6. Shpak AP, Gorbyk PP (2009) Nanomaterials and supramolecular structures: physics, chemistry, and applications. Springer, Dordrecht, p 420. http://www.springer.com/gp/book/97890 48123087

7. Yu J, Yang C, Li J, Ding Y, Zhang L, Yousaf MZ, Lin J, Pang R, Wei L, Xu L, Sheng F, Li C, Li G, Zhao L, Hou Y (2014) Multifunctional $\mathrm{Fe}_{5} \mathrm{C}_{2}$ nanoparticles: a targeted theranostic platform for magnetic resonance imaging and photoacoustic tomographyguided photothermal therapy. Adv Mater 26(24):4114-4120. https://doi.org/10.1002/adma.201305811

8. Ju Y, Zhang H, Yu J, Tong S, Tian N, Wang Z, Wang X, Su X, Chu X, Lin J, Ding Y, Li G, Sheng F, Hou Y (2017) Monodisperse Au-Fe ${ }_{2} \mathrm{C}$ janus nanoparticles: an attractive multifunctional material for triple-modal imaging-guided tumor photothermal therapy. ACS Nano 11(9):9239-9248. https://doi.org/10.1021/acsnano.7b044 61

9. Kopanja L, Kralj S, Zunic D, Loncar B, Tadić M (2016) Core-shell superparamagnetic iron oxide nanoparticle (SPION) clusters: TEM micrograph analysis, particle design and shape analysis. Ceram Int 42:10976-10984. https://doi.org/10.1016/j.ceram int.2016.03.235

10. Tadić M, Kralj S, Jagodic M, Hanzel D, Makovec D (2014) Magnetic properties of novel superparamagnetic iron oxide nanoclusters and their peculiarity under annealing treatment. Appl Surf Sci 322:255-264. https://doi.org/10.1016/j.apsusc.2014.09.181

11. Wang $X$, Zhang $P$, Wang $W$, Lei $X$, Yang $H$ (2016) Magnetic $\mathrm{N}$-enriched $\mathrm{Fe}_{3} \mathrm{C} /$ graphitic carbon instead of $\mathrm{Pt}$ as an electrocatalyst for the oxygen reduction reaction. Chem Eur J 22:48634869. https://doi.org/10.1002/chem.201505138

12. Elmore WC (1938) Ferromagnetic colloid for studying magnetic structures. Phys Rev 54:309-310. https://doi.org/10.1103/PhysR ev.54.309

13. Klabunde K, Sergeev GB (2013) Nanochemistry, 2nd edn. Elsevier, p 372. https://www.elsevier.com/books/nanochemistry/ klabunde/978-0-444-59397-9

14. Cushing BL, Kolesnichenko VL, O'Connor CJ (2004) Recent advances in the liquid-phase syntheses of inorganic nanoparticles. Chem Rev 104:3893-3946. https://doi.org/10.1021/cr030 $027 \mathrm{~b}$

15. Burda C, Chen X, Narayanan R, El-Sayed MA (2005) Chemistry and properties of nanocrystals of different shapes. Chem Rev 105(4):1025-1102. https://doi.org/10.1021/cr030063a

16. Kopanja L, Milošević I, Panjan M, Damnjanovic V, Tadić M (2016) Sol-gel combustion synthesis, particle shape analysis and magnetic properties of hematite (a-Fe2O3) nanoparticles embedded in an amorphous silica matrix. Appl Surf Sci 362:380-386. https ://doi.org/10.1016/j.apsusc.2015.11.238

17. Tadić M, Kusigerski V, Marković D, Panjan M, Milošević I, Spasojević V (2012) Highly crystalline superparamagnetic iron oxide nanoparticles (SPION) in a silica matrix. J Alloys Compd 525:28-33. https://doi.org/10.1016/j.jallcom.2012.02.056

18. Billas IML, Chatelain A, de Heer WA (1997) Magnetism of Fe, Co and Ni clusters in molecular beams. J Magn Magn Mater 168(12):64-84. https://doi.org/10.1016/S0304-8853(96),00694-4

19. Billas IML, Chatelain A, de Heer WA (1996) Magnetism in transition-metal clusters from the atom to the bulk. Surf Rev Lett 3(1):429-434. https://doi.org/10.1142/S0218625X96000772

20. Gubin SP, Koksharov YuA, Khomutov GB, Yurkov GYu (2005) Magnetic nanoparticles: preparation, structure and properties. Russ Chem Rev 74(6):489-520. https://doi.org/10.1070/RC2005v074 n06ABEH000897

21. Roca AG, Costo R, Rebolledo AF, Veintemillas-Verdauguer S, Tartaj P, Gonzales-Carrenno T et al (2009) Progress in the preparation of magnetic nanoparticles in biomedicine. J Phys D Appl Phys 42(22):224002. https://doi.org/10.1088/0022$3727 / 42 / 22 / 224002$
22. Movchan BA, Kurapov YuA, Didikin GG, Litvin SG, Romanenko SM (2011) Control of the composition and structure of Fe-O nanoparticles during $\mathrm{Fe}_{3} \mathrm{O}_{4}$ electron beam evaporation. Powder Metall Met Ceram 50(3-4):167-172. https://doi. org/10.1007/s11106-011-9314-0

23. Kurapov YuA, Krushinskaya LA, Litvin SE, Romanenko SM, Stelmakh YaA, Markiev VYa (2014) Production and thermal stability of silver nanoparticles in the $\mathrm{Ag}-\mathrm{O}$ system. Powder Metall Met Ceram 53(3-4):199-204. https://doi.org/10.1007/s1110 6-014-9604-4

24. Kurapov YuA, Litvin SE, Romanenko SM (2013) Structure and thermal stability of $\mathrm{Ti}-\mathrm{NaCl}$ condensates deposited from the vapour phase in vacuum. Nanostruct Mater Sci (1):55-62. http://www.materials.kiev.ua/science/edition_view.jsp?id=2

25. Kurapov YuA, Litvin SE, Didikin GG, Romanenko SM (2011) Structure of two-phase $\mathrm{Cu}-\mathrm{NaCl}$ condensates, deposited in vacuum from the vapour phase. Adv Electrometall 9(2):8286. https://paton publishinghouse.com/eng/journals/ sem/2011/02/05

26. Kurapov YuA, Romanenko SM, Didikin GG, Oranskaya El (2017) Controllable synthesis of iron oxide nanoparticles in porous $\mathrm{NaCl}$ matrix. Mater Res Express 4(3):035031. https://doi. org/10.1088/2053-1591/4/3/035031

27. Kovinsky IS, Krushinskaya LA, Movchan BA (2011) Structure and some properties of sodium chloride condensates produced by electron beam evaporation with next deposition in vacuum. Adv Electrometall 9(1):42-46. https://patonpublishinghouse .com/eng/journals/sem/2011/01/08

28. Chekman IS, UI'berh ZR, Malanchuk VO, Horchakova NO, Zupanets'IA (2012) Nanoscience, nanobiology, nanofarmation, Kyiv, Polihraf plyus, 328. https://www.twirpx.com/file/1157774/

29. Laurent S, Forge D, Port M, Roch A, Robic C, Elst LV et al (2008) Magnetic iron oxide nanoparticles: synthesis, stabilization, vectorization, physicochemical characterizations, and biological applications. Chem Rev 108(6):2064-2110. https://doi. org/10.1021/cr068445e

30. Santhosh PB, Ulrih NP (2013) Multifunctional superparamagnetic iron oxide nanoparticles: promising tools in cancer theranostics. Cancer Lett 336(1):8-17. https://doi.org/10.1016/j.canle t.2013.04.032

31. Jin R, Lin B, Li D, Ai H (2014) Superparamagnetic iron oxide nanoparticles for MR imaging and therapy: design considerations and clinical applications. Curr Opin Pharmacol 18:18-27. https ://doi.org/10.1016/j.coph.2014.08.002

32. Wang YXJ (2011) Superparamagnetic iron oxide based MRI contrast agents: current status of clinical application. Quant Imag Med Surg 1(1):35-40. https://doi.org/10.3978/j. issn.2223-4292.2011.08.03

33. Rosner $\mathrm{MH}$, Auerbach $\mathrm{M}$ (2011) Ferumoxytol for the treatment of iron deficiency. Expert Rev Hematol 4(4):399-406. https://doi. org/10.1586/ehm.11.31

34. Roohi F, Lohrke J, Ide A, Schutz G, Dassler K (2012) Studying the effect of particle size and coating type on the blood kinetics of superparamagnetic iron oxide nanoparticles. Int J Nanomedicine 7:4447-4458. https://doi.org/10.2147/IJN.S33120

35. Ni F, Jiang L, Yang R, Chen Z, Qi X, Wang J (2012) Effects of PEG length and iron oxide nanoparticles size on reduced protein adsorption and non-specific uptake by macrophage cells. J Nanosci Nanotechnol 12(3):2094-2100. https://doi.org/10.1166/ jnn.2012.5753

36. Briley-Saebo KC, Johansson LO, Hustvedt SO, Haldorsen AG, Bjørnerud A, Fayad ZA et al (2006) Clearance of iron oxide particles in rat liver: effect of hydrated particle size and coating material on liver metabolism. Invest Radiol 41(7):560-571. https ://doi.org/10.1097/01.rli.0000221321.90261.09 
37. Paton BYe, Movchan BO, Kurapov YuA, Yakovchuk KYu (2010) Method of obtaining nanoparticles of metal-oxygen system with given composition by electron beam evaporation and condensation in vacuum, U.A. Pat. \# 92556 from 10.11. 2010, Bull. \# 21/2010, http://base.ukrpatent.org/searchINV/search.php?actio $\mathrm{n}=$ viewdetails\&IdClaim $=151646$

38. Lebedev AD, Levchuk YN, Lomakin AV, Noskin VA (1987) Laser correlation spectroscopy in biology, Kiev, Naukova Dumka, $p$ 255. https://search.rsl.ru/ru/record/01001388286

39. Merkus HG (2009) Particle size measurements. Fundamentals, practice, quality. Springer, http://www.springer.com/gp/ book/9781402090158

40. Доклінічні дослідження лікарських засобів: методичні рекомендації (2001)/наук. ред. Стефанов О.В. К.: Авіцена, р 528. https://www.twirpx.com/file/537410/

41. Антонов ВC, Богомолова НВ, Волков АС (2010) Автоматизация гематологического анализа. Справочник заведующего клинико-диагностической лабораторией; №1, http://www. mcfr.ru/journals/41/256/17837/21349

42. Камышников ВС, Волотовская ОА, Ходюкова АБ (2013) Методы клинических лабораторных исследований, под ред. проф. Камышникова ВС. 6-е изд. М.: МЕДпресс-информ, 736 p., http://www.med-press.ru/upload/iblock/7c7/7c74480a0c 810516688f16c98f54ab0a.pdf

43. Мовчан БА, Демчишин АВ (1969) Исследование структуры и свойств толстых вакуумных конденсатов никеля, вольфрама, оксида алюминия и диоксида циркония, Физика металлов и металловедение 28(4):653-660, http://impo.imp.uran.ru/fmm/ Electron/vol28_4/abstract10.pdf

44. Kaygorodov AS, Ivanov VV, Paranin SN, Nozdrin AA (2007) The role of adsorbats in pulsed compaction of oxide nanopowders. Nanotechnol Russ 2:112-118. http://pleiades.online/ru/journ als/search $/$ ?name $=$ nanotech

45. de Boer JH (1968) The dynamic character of adsorption. Oxford University Press, London, p 240. https://books.google.com.ua/ books?id=e8N4AAAAIAAJ\&hl=ru\&source=gbs_book_other versions

46. Leibnitz E, Struppe HG (1984) Handbuch der gaschromatographie, Akademishe Verlagsgesellschaft Geest \& Porting K.-G., Leipzig, 828 s., http://onlinelibrary.wiley.com/doi/10.1002/ food.19850290727/abstract

47. Nelson CT, Elam JW, Cameron MA, Tolbert MA (1998) George SM (1998) Desorption $\mathrm{H}_{2} \mathrm{O}$ from hydroxylated single-crystal a- $\mathrm{Al}_{2} \mathrm{O}_{3}$ (0001) surface. Surf Sci 416(3):341-353. https://doi.org/10.1016/ S0039-6028(98),00439-7

48. Lj Kundacovic, Mullins DR, Overbury SH (2000) Adsorption and reaction of $\mathrm{H}_{2} \mathrm{O}$ and $\mathrm{CO}$ on oxidized and reduced $\mathrm{Rh} / \mathrm{CeOx}$ (111) surfaces. Surf Sci 457(1-2):51-62. https://doi.org/10.1016/S0039 $-6028(00), 00332-0$

49. Lind K, Kresse M, Debus NP, Muller RH (2002) A novel formulation for superparamagnetic iron oxide (SPIO) particles enhancing MR lymphography: comparison of physicochemical properties and the in vivo behaviour. J Drug Target 10(3):221-230. https://doi.org/10.1080/10611860290022651 